\title{
Self-Centering Seismic Lateral Force Resisting Systems: High Performance Structures for the City of Tomorrow
}

\author{
Nathan Brent Chancellor ${ }^{1, *}$, Matthew R. Eatherton ${ }^{2}$, David A. Roke ${ }^{3}$ and Tuğçe Akbaş ${ }^{1}$ \\ 1 Advanced Technology for Large Structural Systems (ATLSS) Center, Department of Civil and \\ Environmental Engineering, Lehigh University, 117 ATLSS Drive, Bethlehem, PA 18015, USA; \\ E-Mail: tua211@ lehigh.edu \\ 2 Department of Civil and Environmental Engineering, Virginia Tech, 200 Patton Hall, Blacksburg, \\ VA 24061, USA; E-Mail: meather@vt.edu \\ 3 Department of Civil Engineering, The University of Akron, Auburn Science and Engineering Center, \\ 244 Sumner Street, Akron, OH 44325, USA; E-Mail: roke@uakron.edu
}

* Author to whom correspondence should be addressed; E-Mail: brent.chancellor1 @ gmail.com.

Received: 12 June 2014; in revised form: 3 September 2014 / Accepted: 4 September 2014 /

Published: 18 September 2014

\begin{abstract}
Structures designed in accordance with even the most modern buildings codes are expected to sustain damage during a severe earthquake; however; these structures are expected to protect the lives of the occupants. Damage to the structure can require expensive repairs; significant business downtime; and in some cases building demolition. If damage occurs to many structures within a city or region; the regional and national economy may be severely disrupted. To address these shortcomings with current seismic lateral force resisting systems and to work towards more resilient; sustainable cities; a new class of seismic lateral force resisting systems that sustains little or no damage under severe earthquakes has been developed. These new seismic lateral force resisting systems reduce or prevent structural damage to nonreplaceable structural elements by softening the structural response elastically through gap opening mechanisms. To dissipate seismic energy; friction elements or replaceable yielding energy dissipation elements are also included. Post-tensioning is often used as a part of these systems to return the structure to a plumb; upright position (self-center) after the earthquake has passed. This paper summarizes the state-of-the art for self-centering seismic lateral force resisting systems and outlines current research challenges for these systems.
\end{abstract}


Keywords: self-centering; high-performance; resilient; seismic; moment frame; braced frame; shear wall

\section{Introduction}

Structures designed in accordance with even the most modern buildings codes are expected to undergo significant structural and nonstructural damage during a severe earthquake. Structures are typically designed for "life-safety" performance, in which the objective of design is to protect the lives of the occupants during the design basis earthquake (DBE), which has a return period of several hundred years [1]. Damage to the structure may include yielding, buckling or fracture of structural elements and permanent horizontal displacements after the earthquake, referred to as residual drift.

Structures experiencing large residual drifts are removed from service, and buildings requiring structural repair are often out of service for extended periods of time [2]. Repairing structural damage is expensive and time-consuming because the damage is often distributed throughout the structure in many nonreplaceable elements. If the damage is too severe, or if there is significant residual drift, the structure may require demolition. Significant damage to many structures in a large city may result in a disruption of the regional, and in some cases national, economy.

To reduce the economic disruption caused by an earthquake, and to create more resilient, sustainable cities, high-performance structural systems that can withstand strong ground shaking with little or no structural damage (outside of replaceable energy dissipating elements) are needed. To meet this need, a new class of seismic lateral force resisting systems has been developed. These damage-resistant systems reduce or prevent structural damage to nonreplaceable elements by softening the structural response through elastic gap opening mechanisms instead of yielding in primary structural elements. To dissipate seismic energy, friction elements or replaceable yielding energy dissipation elements are also included. Post-tensioning is often used as a part of these systems to return the structure to a plumb, upright position (self-center) after the earthquake has passed. These new seismic lateral force resisting systems are known as self-centering systems.

This paper summarizes the state-of-the art for self-centering seismic lateral force resisting systems for buildings and outlines current research challenges for these systems. First, a brief overview of the motivation for self-centering systems is presented in the context of how conventional seismic systems perform, including an example demonstrating the implications of the conventional design approach. Next, the mechanics and behavior of self-centering systems are described, followed by an overview of several key different types of self-centering systems that have been developed. The paper closes with a discussion of some current research challenges that are currently under investigation.

\section{Motivation for Self-Centering Systems}

\subsection{Conventional Seismic Lateral Force Resisting Systems: Behavior and Drawbacks}

Conventional seismic lateral force resisting systems are designed to dissipate seismic energy through inelastic behavior (i.e., permanent damage) of structural elements. For example, steel moment resisting 
frames (MRFs) are designed to dissipate energy through substantial yielding near the beam ends. For steel concentrically braced frames (CBFs), energy is dissipated through inelastic buckling and yielding of braces. Concrete shear walls dissipate energy through yielding of reinforcing steel and crushing of concrete at the base of the wall. All of these energy dissipation mechanisms, as well as mechanisms for other conventional seismic lateral force resisting systems, are associated with damage to structural elements. Figure 1 schematically shows the expected damage in these conventional structural systems.

Figure 1. Conventional seismic lateral force resisting systems: (a) Steel moment resisting frame; (b) Steel concentrically braced frame; (c) Concrete shear wall.

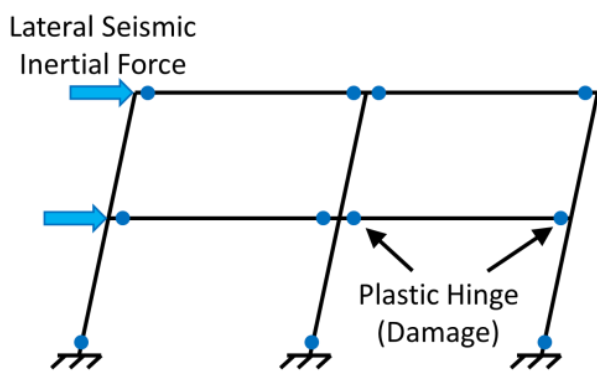

(a)

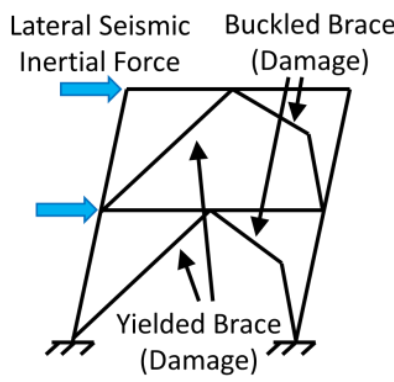

(b)

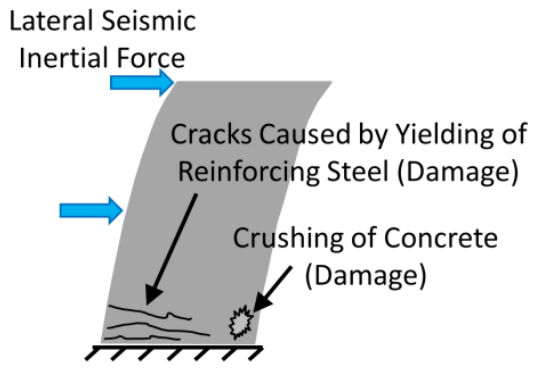

(c)

The hysteretic behavior of a steel MRF is characterized by wide stable hysteresis loops, as shown in Figure 2a. These wide hysteresis loops are traditionally thought to be desirable due to the amount of energy dissipated per cycle of imposed displacement/rotation. However, with this type of hysteretic behavior, large residual drifts are possible when the lateral loads are removed.

The hysteretic behavior of a single brace from a computational simulation of a steel CBF is shown in Figure $2 \mathrm{~b}$. The brace yields in tension, but the brace buckles in compression and its load carrying capacity decreases, leading to pinched hysteresis loops. Buckling of the brace also causes very large local plastic strains near the midpoint of the brace, which can lead to low-cycle fatigue and fracture of the brace. With this type of hysteretic behavior, brace buckling and brace fracture may lead to a loss of lateral load capacity and residual drift.

Figure 2. Hysteretic behavior of conventional structural systems: (a) Steel moment resisting frame (adapted from [3]. Copyright 2013 ASCE); (b) Single steel brace (adapted from [4]. Copyright 2014 Chancellor); (c) Concrete shear wall (from computational simulation).

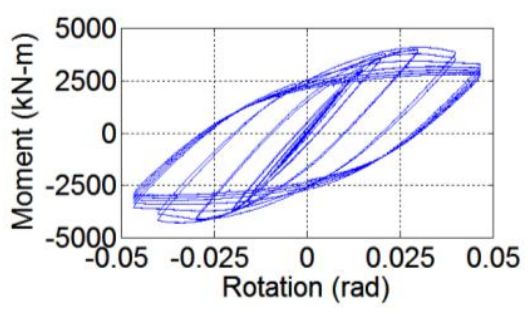

(a)

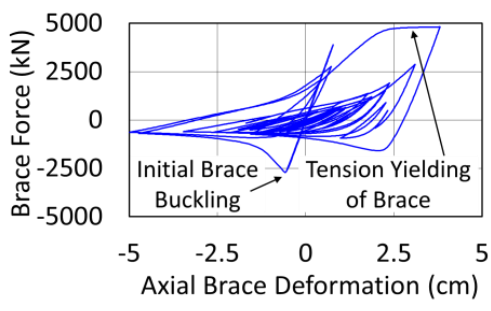

(b)

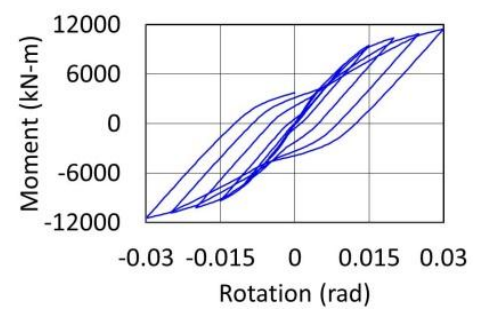

(c) 
The hysteretic behavior of a concrete shear wall from a computational simulation is shown in Figure 2c. The computational simulation performs a nonlinear analysis of the selected concrete shear wall section under an imposed deformation pattern to determine the moment-rotation relationship for the section. This type of hysteretic behavior is known as "stiffness-degrading" because the stiffness upon reloading the structure in the opposite direction is less than the stiffness of the previous cycle. With stiffness-degrading hysteretic behavior, less energy is dissipated per cycle than with a steel MRF, but the degrading stiffness behavior introduces some re-centering characteristics. Therefore, the residual drift at the end of an earthquake may be less than some other types of structural systems, though structural damage is still present.

\subsection{Need for High-Performance Seismic Lateral Force Resisting Systems}

The magnitude 6.3 earthquake that occurred in Christchurch, New Zealand in February 2011 is a prime example of the need for more resilient earthquake-resistant structural systems. Shortly after the earthquake, approximately $50 \%$ of the buildings in the central business district were declared unusable because they sustained significant damage or because they were adjacent to hazardous buildings [5] and nearly 1000 buildings in the central business district were subsequently demolished [6]. The estimated cost for rebuilding after this earthquake is $\$ 40$ billion (New Zealand Dollars), which amounts to approximately $20 \%$ of New Zealand's GDP, without including economic losses associated with business downtime. As of May 2014, the Christchurch reconstruction is still underway [7].

Conventional seismic lateral force resisting systems depend on inelasticity in primary structural elements to resist collapse; therefore, most of these systems are inherently inefficient in limiting structural damage or residual drifts. New structural systems are therefore necessary to address performance goals associated with reducing structural repair costs and business downtime. These systems are known as "selfcentering" systems due to their inherent ability to return to a plumb, upright condition after an earthquake. The remainder of this paper reviews the state-of-the-art in self-centering seismic lateral force resisting systems and outlines future research challenges for these systems.

\section{Self-Centering Seismic Lateral Resisting Systems-Overview of Behavior}

There are several key aspects of self-centering system mechanics and behavior. The first characteristic is the restoring force component that often utilizes a gap opening mechanism. The restoring force component combines with an energy dissipating element to produce flag-shaped load-deformation behavior. The shape of the hysteretic response can be tuned by the proportion of restoring force and energy dissipation components. Other key topics discussed in this section include self-centering ability in full buildings, controlling the progression of limit states, and designing for appropriate ductility demands.

\subsection{Restoring Force Mechanism and Gap Openings}

Self-centering seismic lateral force resisting systems are capable of fully re-centering when the lateral forces are removed (herein referred to as full self-centering), eliminating residual drift. In contrast to full self-centering, attempts have been made to reduce residual drifts in buckling restrained braced frames by using a linear-elastic backup moment frame as a restoring force [8]. This expected load-deformation 
behavior for this type of system is shown in Figure 3a, where the backup system providing a linear elastic restoring force is combined with an elastic-perfectly plastic lateral force resisting system to potentially reduce residual drifts through probabilistic self-centering. Probabilistic self-centering is described in detail later. Full self-centering, however, is usually achieved using a nonlinear elastic restoring force such as the bilinear elastic restoring force shown in Figure 3b.

Figure 3. Need for nonlinear elastic restoring force to create full self-centering. (a) Added restoring force, but not full self-centering; (b) Full self-centering made possible by nonlinear elastic restoring force.

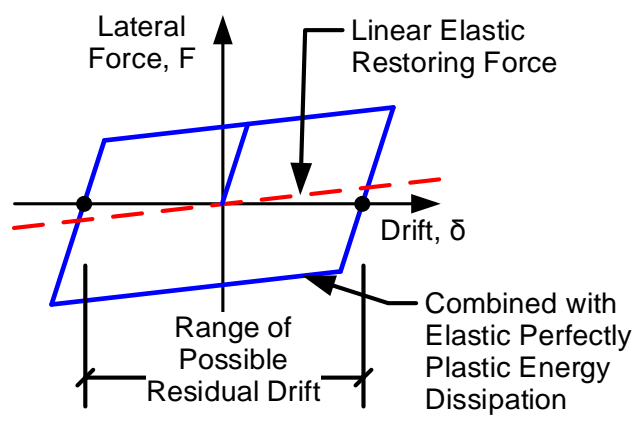

(a)

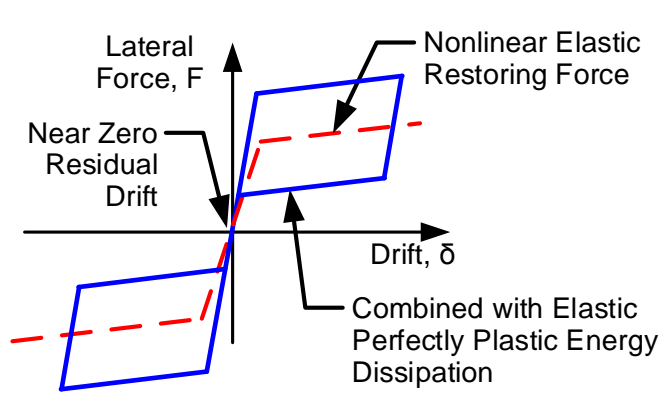

(b)

The most common approach for creating a bilinear elastic restoring force involves gaps forming between two surfaces that are initially precompressed together. Figure 4a schematically shows three categories of restoring force mechanisms that use this gap opening behavior. The first category, which includes rocking precast concrete walls (e.g., [9]), precast concrete columns (e.g., [10]), or rocking steel concentrically braced frames (e.g., [11]), forms a gap at the foundation when subjected to a prescribed overturning moment. When the lateral forces causing the overturning moment are removed, vertical unbonded post-tensioning (PT) steel pulls the structure back to a vertical, plumb condition, closing the gap. The second restoring force mechanism category includes self-centering moment resisting frames, such as precast concrete moment frames (e.g., [12]), steel moment frames (e.g., [13]), or coupled concrete shear walls (e.g., [14]), which allow gap opening between beam and column (or wall) joints when subjected to a prescribed moment. When the lateral forces causing the moment are removed, the gap is closed by compression forces provided by unbonded horizontal PT steel. The third restoring force mechanism category includes self-centering braces, in which a gap forms between telescoping concentric tubes and anchorage plates (e.g., [15]) when subjected to a prescribed axial force. Once the axial force is removed, the gap is closed and the tubes are brought back into alignment by PT steel oriented longitudinally along the length of the concentric tubes. 
Figure 4. Methods for creating bilinear elastic restoring force using gap opening or shape memory alloys (SMA). (a) Gap opening mechanisms; (b) Restoring force associated with gap openings; (c) Nonlinear elastic behavior of SMA.

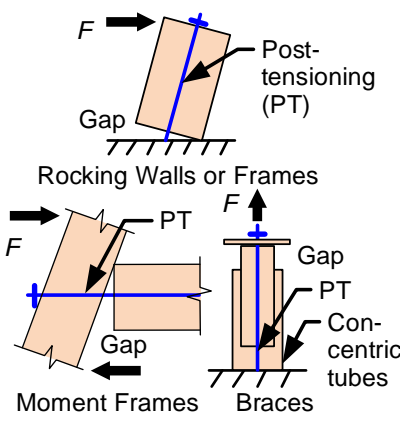

(a)

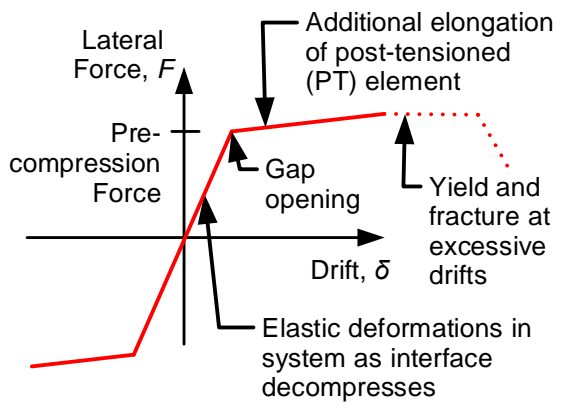

(b)

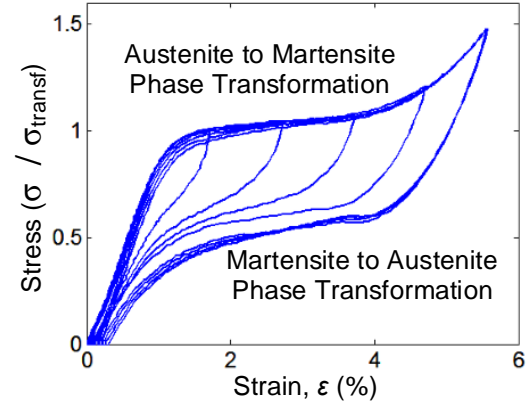

(c)

Although these systems allow gap opening at different locations, the restoring force mechanisms function identically. As shown in Figure 4b, at low levels of lateral force, the seismic lateral force resisting system behaves elastically. Once the lateral force becomes large enough to overcome the precompression force provided by the PT steel, the selected joint decompresses and a gap opens. At decompression there is a significant reduction in the stiffness of the lateral force resisting system. This reduction in stiffness is desirable because it lengthens the period of the structure and helps to limit the forces that can develop in the lateral force resisting system (i.e., softening occurs without structural damage). Because the bearing surfaces at the location of gap opening in a real structure are not all perfectly flat and the members are not exactly the same length, the actual load-deformation response may have rounded corners (e.g., [16,17]) rather than the sharp corners illustrated schematically in Figure $4 \mathrm{~b}$. The stiffness of the system after gap opening is primarily controlled by the axial stiffness of the PT steel and the location of the PT steel. If the PT steel is subjected to strains greater than the elastic limit, yielding and fracture may occur. The amount of inelastic strain capacity prior to fracture of the PT steel is a function of the type of PT steel system used.

Many types of PT steel systems have been used in self-centering systems. In most rocking self-centering systems and self-centering moment frames, the PT steel component consists of high strength PT strands or bars $[13,14,18]$. PT strands have higher ultimate stress, $F_{\mathrm{pu}}=1861 \mathrm{MPa}$, than PT bars, and have a large yield strain, which is usually taken as $1 \%$ [13]. However, the inelastic strain capacity of some PT strand systems is limited because the wedge anchorage system may cause stress concentrations in the strands [19]. This PT strand and wedge anchorage system results in mean strains at failure of $2.3 \%$ with a standard deviation of $0.5 \%$ for conventional $12.7 \mathrm{~mm}$ PT strands with multi-use chuck anchorages. PT bars have lower ultimate stress, $F_{\mathrm{pu}}=1030 \mathrm{MPa}$, and a smaller yield strain of $0.5 \%$, but have significantly larger inelastic strain capacity that can be as high as $10 \%$.

Self-centering braces typically have a short PT element length, such that it is often not practical to use steel PT because the axial deformation at yield of the PT steel is too small. Therefore, aramid fiber strands (which have an elastic strain capacity up to 4\% [15]) or shape memory alloys with superelastic behavior up to $6 \%$ strain (e.g., [20]) have been used in self-centering braces. Figure $4 \mathrm{c}$ shows that the load-deformation response for a $23 \mathrm{~mm}$ round SMA rod subjected to cyclic tension (from [17]) exhibits the prerequisite nonlinear elastic behavior without requiring a gap opening mechanism. Double 
telescoping mechanisms have also been developed to reduce the strain demands on the PT element in self-centering braces (e.g., [21,22]).

Wherever a gap opening mechanism is allowed in a rocking or moment frame system, shear resistance across the joint interface must be considered in design. Precast concrete rocking walls [23] and precast concrete moment frames (e.g., [12]), in general, rely on friction at the joint interface to transfer shear force. As such, joint interface details (e.g., grout beds) that can develop high coefficients of friction are critical. Shear transfer across the base joint interface in steel rocking frames usually occurs through a steel curb or bumper at the column base or through an armored trough in the foundation (e.g., $[11,16])$ in addition to friction at the joint interface. Alternatively, yielding base plates may be used to transfer shear at the column base (e.g., [24]). Steel moment frames primarily use friction between the beam end and column face to transfer shear, but also have some redundancy for shear transfer supplied by the energy dissipation device, whether a friction damper [25], yielding angles [26], or short yielding bars [27]. Although self-centering braces are subjected primarily to axial forces, it is still necessary to restrain lateral motion of the concentric tubes using spacers or guides [15,17].

\subsection{Energy Dissipation Options}

Gap opening and the force in the PT steel provide the bilinear elastic self-centering behavior shown in Figure $4 b$, but do not provide energy dissipation to the structure. Computational studies on single degree of freedom structures suggest that there is a minimum amount of energy dissipation required for bilinear elastic (self-centering) systems to produce peak drifts similar to those of conventional bilinear elastic-plastic systems [28-30]. To produce sufficient energy dissipation, an energy dissipating element is incorporated into self-centering systems. Since self-centering seismic systems are implicitly designed to meet higher performance objectives to minimize repair costs and business downtime, energy dissipation elements should be designed to allow replacement after large earthquakes. Energy dissipating elements can be broadly categorized as hysteretic damping elements, viscous damping elements, and frictional damping elements.

A wide range of hysteretic energy dissipation devices have been used in self-centering systems. Axial acting hysteretic energy dissipating elements include: buckling restrained braces [17,31,32], short yielding elements similar to buckling restrained braces [27,33], unbonded mild steel reinforcement (e.g., [10,12]), reinforcing steel bars with reduced sections [9], and yielding anchor bolts [34]. Hysteretic energy dissipating elements that yield in a combination of shear and flexure include butterfly fuse plates [35], yielding end plates [24,36], yielding angles [26,37], web hourglass pins [38], and tapered steel cantilever plates [39].

Several types of frictional damping elements have been used in self-centering systems. These systems usually consist of two or more plates that slide relative to each other, although configurations are possible such as the Ringfeder spring which dissipates energy through friction and contributes restoring force [40]. Typically, the friction plates are clamped together with bolts or with a combination of bolts and spring washers to provide a normal force [25]. A special wearing surface is often placed between the plates to achieve a more consistent coefficient of friction. Cartridge brass [25,41] and automotive brake pads [15] have been used as wearing surfaces. It can be challenging to get consistent performance in friction damping elements. Some of the challenges include degradation of friction surfaces over time, changes 
in the friction coefficient during cyclic loading due to wear of the friction surfaces, and maintaining a consistent normal force. To achieve consistent performance of friction damping elements, these challenges must be addressed. In addition to hysteretic and friction damping elements, viscous damping elements have been proposed for use at the column bases of rocking frames [42].

As an alternative to clamped-plate frictional elements, a mode of frictional energy dissipation with unique dynamic properties has been developed wherein friction is encouraged at the interface connection between the lateral force resisting system and the gravity system in rocking braced frames [11]. An additional non-uplifting gravity column is placed adjacent to the uplifting rocking braced frame column. Lateral inertial forces are transferred from collector elements attached to the adjacent gravity column through lateral load bearings into the rocking braced frame. As the braced frame column uplifts, it moves relative to the non-uplifting adjacent gravity column. Energy is dissipated in the lateral load bearings through frictional forces and relative sliding. The frictional force is proportional to the applied lateral inertial force. When the earthquake ceases and lateral inertial forces are removed, the friction forces are virtually eliminated, resulting in improved self-centering ability.

\subsection{Proportioning the Restoring Force Mechanism and Energy Dissipation Elements}

The capacity of the self-centering seismic system to resist lateral loads is characterized by the sum of the resistances due to the restoring forces (PT force, gravity loads) and the force in the energy dissipation element. The sum of these two capacities must be greater than the effect of the design lateral forces calculated based on the procedures for structural system design lateral force calculations in the governing building code.

The height of the hysteresis loop (as defined by $\beta$ or $\beta_{\mathrm{E}}$ in Figure 5) for a self-centering system is a function of the strength and location of the energy dissipation elements. Figure 5 assumes an energy dissipation element with a static force capacity (e.g., friction plates [25]). Incorporating viscous dampers in addition to a static energy dissipation element can reduce peak displacements and result in more consistent performance [43], but cannot be readily quantified in standard force-deformation plots like the one shown schematically in Figure 5 due to the velocity dependence of the damper forces.

Figure 5. Self-centering criteria for SC systems: (a) $\beta \leq 1.0$ (adapted from [28]. Copyright 2002 John Wiley \& Sons, Ltd.); (b) $\beta_{\mathrm{E}} \leq 0.5$ (adapted from [29]. Copyright 2005 ACI).

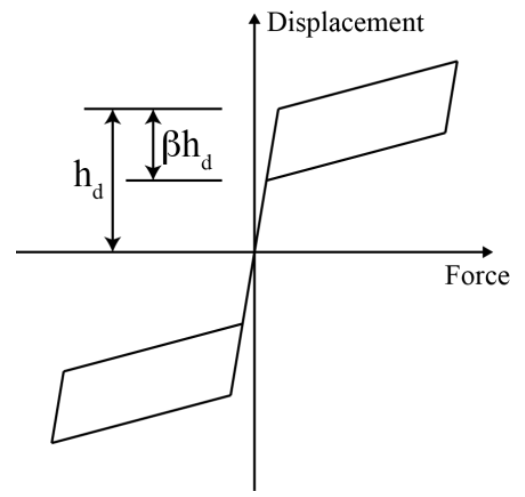

(a)

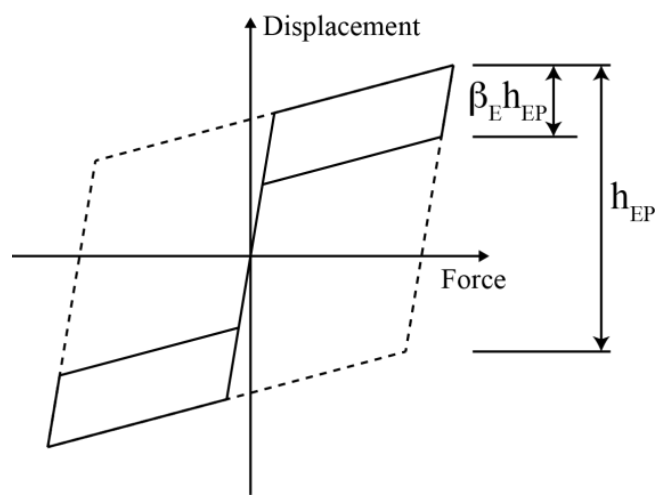

(b) 
The flag-shaped hysteresis demonstrates self-centering ability since the displacement returns to negligible values when the lateral forces are removed; however, the system should be proportioned such that this self-centering can occur. One method for defining self-centering capability is based on the relative height of the hysteresis loop, quantified as $\beta$ in Figure 5a [28]. For the system to fully self-center, $\beta \leq 1.0$. Alternatively, another parameter that has been used to quantify self-centering capability in the literature is defined based on the relative area contained (i.e., energy dissipated) in the self-centering hysteresis loops with respect to the area of a comparable bilinear elastoplastic hysteresis loop. If the hysteretic behavior is assumed to be a perfect flag shape, the ratio of energies is equal to the ratio of heights, $\beta \mathrm{E}$, as shown in Figure 5b [29]. For the system to fully self-center, $\beta_{\mathrm{E}} \leq 0.5$. $\beta_{\mathrm{E}}$ is a comparison of the amount of energy dissipated by a self-centering system relative to a conventional bilinear elastoplastic system with identical initial and secondary stiffness.

Regardless of the metric, self-centering capacity is adjusted by tuning the relative magnitudes of the initial PT force (which sets the capacity at decompression, when elastic behavior softens due to gap opening) and the capacity of the energy dissipation elements (which controls the height of the hysteresis loop). Procedures to control the magnitude of residual displacements when the lateral forces are removed can be found in the literature for specific self-centering systems (e.g., $[11,16,44,45])$.

\subsection{Probabilistic Self-Centering and the Resistance of the Rest of the Building}

It has been observed that systems that do not fully prevent residual drift when the lateral force is removed (not full self-centering) can still limit residual drift if the system has a restoring force component consisting of either a nonlinear elastic restoring force (e.g., gap openings with PT steel) or an elastic restoring force that adds kinematic hardening to the system (as shown in Figure 3a). This type of partial self-centering has been referred to as dynamic stability [46] or probabilistic self-centering [30] and occurs as a result of an increased probability of yielding of the system toward plumb rather than away. Figure 6a shows a schematic diagram of the hysteretic response and potentially large residual drifts for a system without full self-centering. However, if the system is at point B in Figure 6a, and there is equal probability of further positive or negative inertial force from ground shaking, then the hysteretic behavior of the system implies that there is a higher probability of reaching the smaller magnitude yield force in the direction of zero displacement than reaching the larger magnitude yield force away from the direction of zero displacement. Many response history analyses [30,47,48] and several shake table tests [32] have demonstrated that the majority of displacement cycles are concentrated in a narrow band as shown in Figure 6a. Systems in which the restoring force was half of the yield force associated with the energy dissipation element were found to exhibit residual drifts less than the out-of-plumb tolerance for new steel buildings for $98 \%$ of the response history analyses subjected to severe ground motion (2\% probability of exceedance in 50 years) $[30,47]$. 
Figure 6. Probabilistic self-centering and the resistance of the rest of the building to self-centering. (a) Probabilistic self-centering concept; (b) Lateral resistance of typical partition wall (adapted from [49]. Copyright 1999 ASCE).

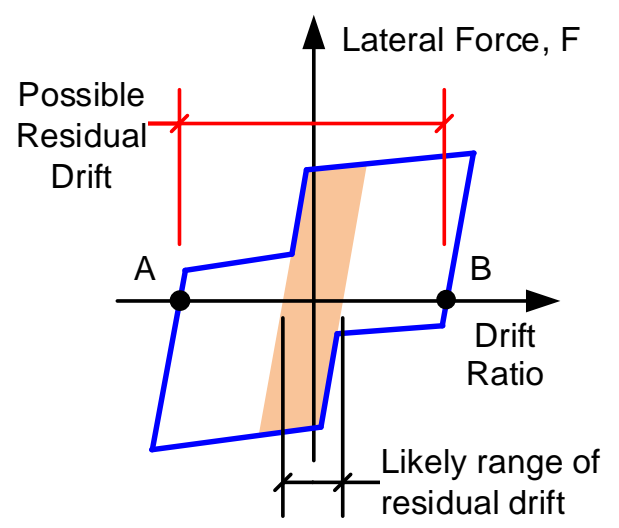

(a)

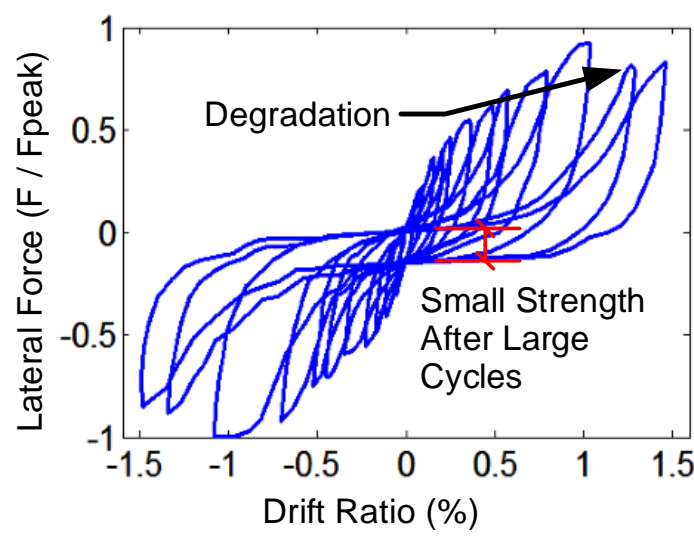

(b)

Lateral load resistance provided by gravity framing may also have an effect on the self-centering capacity of structural systems, though the lateral load resistance of gravity framing and nonstructural components in a structure is often ignored in seismic design because the resistance can be hard to predict and neglecting it is typically assumed to be conservative. However, in the context of self-centering, components of the rest of the building can undergo inelastic actions that produce forces in opposition to the restoring force as the self-centering system attempts to bring the rest of the building back to a plumb position. A non-exclusive list of building elements that contribute to building resistance, but are typically neglected, includes: interior partitions, simple shear beam-to-column connections, stair stringers, horizontal floor diaphragms, floor coverings, ceilings, mechanical systems, and exterior cladding (e.g., precast concrete panels, stucco, brick, glass curtain walls). Figure $6 \mathrm{~b}$ represents the load-deformation response of a typical interior partition wall made of metal studs with gypsum wall board covering both sides [49]. The hysteretic behavior of gravity framing connections and nonstructural components like partition walls can experience significant degradation, pinched hysteretic behavior, and have small residual strength after large displacement cycles. Therefore, while their consideration in response history analyses can significantly reduce peak drifts, non-structural components generally do not hinder the ability of the self-centering system to control residual drift [30].

\subsection{Limit States and the Desired Limit State Progression}

Most self-centering systems have at least four fundamental limit states [50-52] and while actual limit states vary depending on system configuration, it is instructive to examine these limit states in a general context. These limit states are: (1) decompression at the location where gap opening occurs coupled with yielding of hysteretic energy dissipation elements or slip on friction damper interfaces; (2) yielding of the PT elements; (3) limited damage to structural elements; and (4) severe damage to structural elements. Depending on the system, there may be other limit states to consider (e.g., shear slip in panels of precast concrete rocking walls). Concrete rocking wall systems further divide the decompression limit state into decompression of the extreme outside edge of the wall and the effective linear limit of the wall [52,53]. Limited damage of self-centering concrete rocking walls includes cracking and spalling of cover 
concrete at the base of the wall [52], while severe damage can include crushing of confined concrete in wall boundary elements [52-54]. Limited damage of self-centering rocking braced frames includes yielding of frame members, while severe damage involves frame member failure (i.e., loss of load-carrying capacity) [50]. For rocking concrete walls and rocking steel braced frames, yielding of the PT steel may be classified as limited or severe damage depending on if PT bars (limited) or PT strands (severe) are used; PT strand systems may have difficulty achieving significant inelastic strain capacity before fracture [19], while some PT bar systems can achieve significant inelastic strain capacity before fracture [18,55] and composite PT materials do not exhibit yielding prior to fracture [15]. Limited damage in self-centering steel moment resisting frames includes panel zone yield, beam bearing yield at the column face, and horizontal shear yield in the beam web [51,56], while severe damage can include beam local buckling or PT strand yielding [51,56].

The purpose of self-centering seismic lateral force resisting systems is to reduce or eliminate structural damage and residual drift under design level earthquakes so as to enable the possibility of immediately reoccupying the structure after the earthquake. In order to achieve this goal with self-centering systems, a specific limit state progression is targeted in the design of these systems [50,54,56]. Figure 7 shows a schematic of the desired limit state progression for self-centering systems using PT bars and PT strands. Decompression at the gap opening location is the first limit state to occur. At this point there is a reduction in stiffness of the lateral force resisting system, but the structure still behaves elastically. Here, yielding of hysteretic energy dissipation elements or sliding in friction energy dissipation elements is assumed to occur at decompression. The second limit state in the desired limit state progression depends on the type of PT steel used and the type of self-centering system. If PT bars are used with either rocking concrete walls or rocking steel braced frames, then the second limit state is PT steel yielding. If PT strands are used or the system is a moment resisting frame, then the second limit state is limited damage to the system. The third limit state in the progression for rocking concrete walls or rocking steel braced frames is limited damage to the structure. The final limit state for all self-centering systems is severe damage of structural members.

Figure 7. Limit state progression for self-centering systems. (a) Self-centering system using post-tensioning (PT) bars; (b) Self-centering system using PT strands.

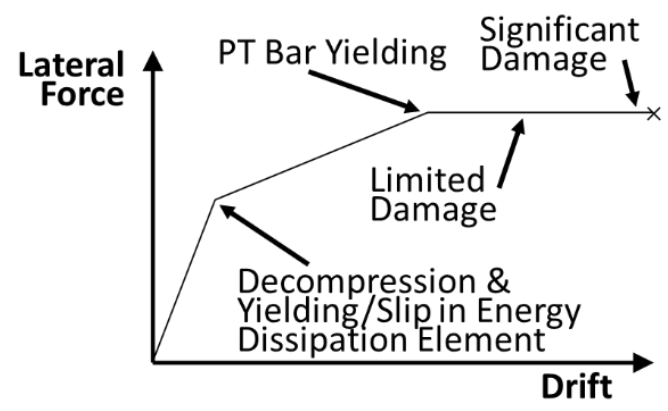

(a)

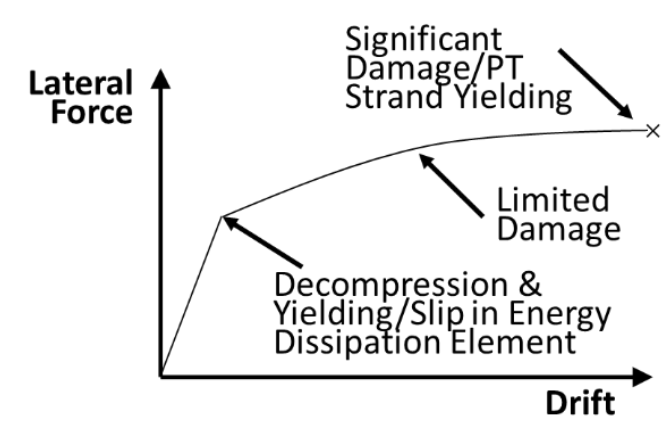

(b)

\subsection{Ductility Demands}

The hysteretic behavior of self-centering structural systems is characterized by flag-shaped hysteresis loops and is fundamentally different from conventional structural systems. Therefore, traditional 
relationships between the strength, period, and ductility demand for a structure, such as the so-called "equal displacement" rule, may not be valid for self-centering systems [28,29,57]. Studies of ductility demands on self-centering single degree-of-freedom systems show that for systems with low energy dissipation, the ductility demand can be significantly higher for self-centering systems than for bilinear elastoplastic hardening systems with identical initial and secondary stiffness [28,29,57]. On the other hand, studies have shown that if the post-yield stiffness and energy dissipation ratio (e.g., $\beta=0.5-1.0$ ) are sufficient, that peak drifts can be similar to elastic perfectly plastic systems $[28,29,58]$.

The increased ductility demand in self-centering systems can occur across nearly all periods and is more noticeable when the system strength is low. Predictive relationships for ductility demand in self-centering systems have been developed that account for the influence of the period of the structure, the strength of the structure (using a response modification factor, $R$ ), the amount of energy dissipated $(\beta \mathrm{E})$, the post-decompression stiffness relative to the initial elastic stiffness $\left(\alpha_{k}\right)$, and the site soil type [57]. These predictive relationships were developed from studies of SC single degree-of-freedom structures subjected to various ground motion sets. These ground motion sets consisted of large magnitude (6.7-7.6) ground motions with a distance of less than $30 \mathrm{~km}$ and were organized based on the soil type at the site of the ground motion recording station. The ground motions were scaled to reduce the dispersion about the mean spectrum of the ground motion set over a period range. Figure 8 shows the ductility demand ( $\mu \mathrm{DBE})$ from these predictive relationships for a site with Type D soil.

Figure 8. Ductility demands from predictive relationships [57] for a self-centering system on Type D soil.

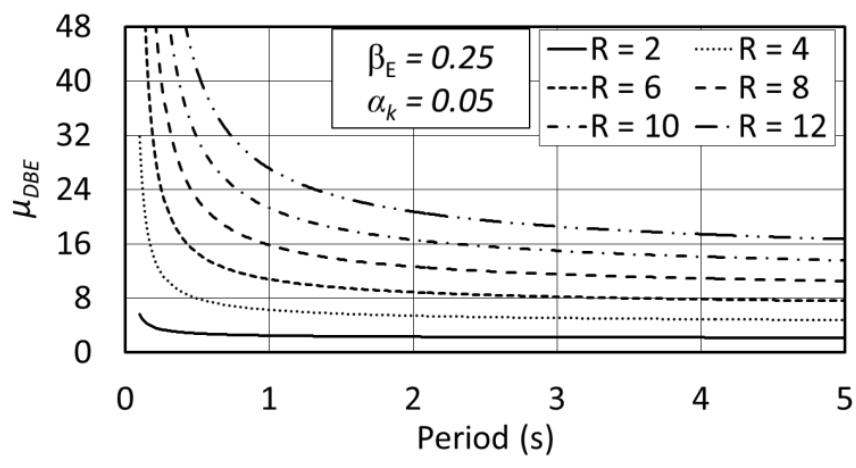

\section{Self-Centering Seismic Lateral Resisting Systems}

A wide variety of self-centering seismic lateral force resisting systems have been developed over the past two decades, beginning with the precast concrete moment frames studied in the PRESSS research program [59]. Self-centering was then adapted for use in concrete shear walls (e.g., [52]), steel moment frames (e.g., [13]), and steel concentrically braced frames (e.g., [11]). This section provides a brief summary of recent research into specific self-centering seismic lateral resisting systems.

\subsection{Rocking Systems}

Gap opening, typically at the base of the wall or frame (see Figure 4a), provides rocking systems' nonlinear softening behavior while still allowing the structure to remain elastic. The rocking response 
significantly decreases the lateral stiffness of the system relative to the initial elastic stiffness, and coupled with yielding of PT steel, effectively limits the peak base overturning moment that can develop. Main structural elements can then be designed to remain nominally elastic (undamaged) for this peak base overturning moment. Energy dissipation is achieved through the implementation of replaceable fuse elements (e.g., [60]), viscous dampers (e.g., [42,43]), or through friction (e.g., [11]). The following subsections further categorize and describe rocking systems as post-tensioned precast concrete shear walls, rocking steel frames, and vertically post-tensioned rocking steel frames. Although there is substantial literature related to free rocking systems (e.g., a stone monument rocking on its foundation) and their unique issues such as tipping over, this summary focuses on seismic systems that limit uplift to be relatively small compared to the width of the rocking element.

\subsubsection{Post-Tensioned Concrete Shear Walls}

Conventional precast concrete shear walls have high stiffness, but limited drift capacity before significant damage occurs as they are typically designed to emulate the behavior of cast-in-place concrete shear walls. Several researchers have adapted self-centering techniques, such as gap opening, to allow these systems to exhibit better seismic performance than emulative walls. The system has been implemented in practice in different forms (examples are given in [61]).

A system of unbonded post-tensioned precast concrete walls that allow gap opening at horizontal joints located at each floor level has been developed (e.g., [52]). Vertical unbonded PT bars or tendons provide a positive stiffness after gap opening, as well as a restoring force mechanism, as the PT force acts to close the gap. The lateral load behavior of this system was demonstrated through large-scale experiments [54,62-64]. Experimental results show that the unbonded post-tensioned precast concrete walls self-center and demonstrate better performance than conventional precast concrete shear walls (e.g., [63]).

A number of energy dissipation sources have been studied for unbonded post-tensioned precast concrete walls, including: mild reinforcing steel across the horizontal joints [62], U-shaped flexural plate connectors between two adjacent shear walls [65], dog-bone shaped energy dissipators [66], and small external energy dissipation devices that act similar to buckling restrained braces [67]. Friction damping between adjacent walls can also be used to dissipate energy [41].

A coupled rocking wall system has been developed in which gap opening may form at the end of the coupling beams as well as the base of the wall [68]. The degree of coupling of the post-tensioned precast concrete shear walls can be varied using the post-tensioned coupling beams. Experimental results indicate that the system can be designed to have high strength, ductility, and energy dissipation capacity [14].

\subsubsection{Rocking Steel Braced Frames (Without Post-Tensioning)}

Rocking braced frame systems have been studied for decades (e.g., [69]). Rocking frames have been implemented in New Zealand in bridges as early as 1981 and in a building in 2007 [61]. Recent research in damage-free structural systems has increased the visibility of such systems outside of New Zealand. These systems allow gap opening, but do not have PT across the joint and rely on gravity loads for self-centering. 
Investigation of rocking steel concentrically braced frames goes back to the 1970s [69,70]. Through the years, shake table tests and computational simulations of rocking steel frames $[24,31,36,42,70]$ have shown that allowing base uplift can reduce the peak base shear, peak accelerations, and peak member forces compared to a similar structure with elastic behavior and fixed bases. A wide range of energy dissipation elements have been used including yielding column base plates that allow uplift [24], similar yielding splice plates along the height of braced frame columns [36], torsional yielding bars [70], buckling restrained braces [31], and viscous dampers [42].

Since these systems rely on gravity loads to provide the restoring force that closes the base uplifting gap, the balance between the yield capacity of the energy dissipating element and the expected actual gravity loads is important. This design approach is effective in structures with large gravity loads such as bridge piers (e.g., [31]), but may not be appropriate for structures where little gravity load is applied directly to the rocking frame (e.g., short structures).

\subsubsection{Post-tensioned Rocking Steel Braced Frames}

Similar to systems described in the previous section, post-tensioned rocking steel braced frames have high initial stiffness (similar to that of conventional concentrically braced frames) but can withstand intense earthquakes with little or no structural damage. By introducing post-decompression stiffness through PT steel, these systems can further limit the peak drifts as compared to rocking systems without vertical PT steel.

Several configurations of post-tensioned rocking steel braced frames have been studied (e.g., [50,71-73]). In all of these configurations, gap opening is allowed at the base of the braced frame and vertical oriented PT steel is used to prestress the braced frame to the foundation. In some configurations (e.g., [71]), two coupled adjacent rocking concentrically braced frames were used while others consist of single rocking frames (e.g., [32,74]). In some configurations [11,74], the gravity system and lateral force resisting system were separated by introducing additional gravity columns adjacent to the rocking braced frame columns. This separation of the gravity and lateral system eliminates damage to the floor diaphragm when the braced frame rocks.

Multiple sources of energy dissipation have been studied for post-tensioned rocking steel braced frames, including yielding steel elements [60,71-73], friction bearings [11,74], and viscous damping elements [73].

Experimental and analytical results show that post-tensioned rocking steel braced frames can significantly reduce the probability of member yielding with respect to conventional systems and that the system self-centers after seismic excitation even after significant PT bar yielding [11]. Large-scale static [71] and shake table [72] testing indicate that post-tensioned rocking steel braced frames effectively concentrate structural damage in the replaceable fuse elements and self-center after seismic excitation. An analytical study indicated that post-tensioned rocking steel braced frames can significantly improve performance of structural and nonstructural components as shown by reduced drifts and accelerations with respect to conventional ductile systems [73]. The system has been implemented in buildings in the U.S. and New Zealand (e.g., [40,75]).

Research into post-tensioned rocking steel braced frame response indicated that higher mode effects significantly increase member force demands compared to those expected based on a pushover 
analysis [74]. These higher mode effects should be accounted for in design so that the braced frame members remain elastic under seismic loading. Several methods have been proposed to account for higher mode effects including modal load factors [11] and a force amplification design procedure [16].

As an alternative to designing members to remain elastic under higher mode effects, mitigation techniques have been studied (e.g., [76]) to reduce the required strength for members to remain elastic. Two higher mode response mitigation techniques that have been studied [77] are: (1) introduction of multiple rocking sections, in which gap opening is permitted at multiple locations throughout the height of the frames; and (2) a force-limiting brace member in the first story, which limits the base shear capacity of the system. Shake table testing [78] demonstrated the effectiveness of the proposed higher mode mitigation techniques.

\subsection{Self-Centering Moment Resisting Frames}

Conventional moment resisting frames are designed with so-called strong-column weak-beam criteria to dissipate seismic energy by forming plastic hinges at the beam ends and at the base of the first story columns to form a global beam-sway mechanism. Although the structure is expected to behave in a ductile manner and dissipate a significant quantity of seismic energy, there may be significant inelastic residual deformation. As an alternative to conventional moment resisting frames with rigid beam-to-column connections, self-centering moment resisting frames that allow a gap to form at the beam-column interface have been developed using both precast concrete and structural steel. This section summarizes published research on concrete and steel self-centering moment resisting frames.

\subsubsection{Concrete Self-Centering Moment Resisting Frames}

Self-centering concrete moment frames consist of concrete beams and columns horizontally post-tensioned together so that a gap can open at the beam-column interface when subjected to a specific applied moment, as shown in Figure 4a. Energy dissipation is supplied at the beam-to-column joint through a variety of mechanisms such as unbonded mild reinforcing steel [64], friction damping elements [79] and other devices.

The early development of concrete self-centering moment resisting frames came out of the PRESSS project during the 1990s [64,80,81]. The purpose of the PRESSS project was to develop recommendations for the seismic design of precast concrete seismic structural systems and develop new materials, concepts and technologies for precast concrete seismic structural systems [80]. Self-centering concrete beam-to-column connections accommodated large rotations without a loss in load carrying capacity [81]. Tests of a five story precast concrete moment resisting frame incorporating self-centering connections and designed using displacement-based design principles showed that drifts were not excessive (e.g., residual drift after DBE was $0.06 \%$ ), and that the self-centering connections suffered little or no damage [64]. The damage was limited to spalling of cover concrete in the beams immediately adjacent to the columns and some crushing of the fiber grout pads at the beam-column interfaces [64]. Self-centering concrete moment frames have performed well in laboratory seismic testing, have been shown to limit damage to the structure, and have been implemented in practice (e.g., [61,82]). 


\subsubsection{Steel Self-Centering Moment Resisting Frames}

Similar to concrete self-centering moment resisting frames, steel self-centering moment frames consist of steel beams and columns post-tensioned together so that a gap can open at the beam-column interface when subjected to a specific moment, as shown in Figure 4a. Energy dissipation devices for the steel SC moment resisting frames have included yielding seat angles [13,26,83], short axial yielding devices similar in behavior to buckling-restrained braces [27], yielding web hourglass pins [38], friction devices at the bottom flange of the beam [84] or at both flanges [85], friction devices at the web of the beam $[41,56,86]$, and yielding thin steel plate infill walls [87-89].

Numerous tests of steel self-centering moment resisting frame beam-to-column connections (e.g., $[26,27,82,84,85,90]$ ) show reliable self-centering behavior of the connection. However, it was noted for one test of a beam-to-column connection with PT strands that individual wires in some of the PT strands fractured in the anchorage grips before reaching the ultimate strength of the strand [26]. Fracture of wires in strands was also noted for rocking braced frame tests using PT strands at strains of about 1\%; although the fracture of one wire did not propagate to other wires in the strand [71]. To increase the ductility of self-centering moment resisting frame beam-to-column connections at ultimate states, design equations and detailing requirements were proposed in accordance with finite element analyses and experimental results for possible plastic hinge locations in the beams [91].

Large-scale frame tests of steel self-centering moment resisting frames [41,86,92] showed considerably better seismic performance compared to conventional moment resisting frames. Steel self-centering moment resisting frames are generally expected to remain undamaged during the DBE, allowing immediate occupancy of the structure and to prevent collapse under the maximum considered earthquake (MCE) [86]. In this case, an MCE event is defined as an intense earthquake with a return period of about 2500 years [1].

During DBE level tests, the peak drift ranged from $1.8 \%$ to $4.9 \%$, but the frame self-centered with residual drift ratios less than $0.1 \%$ [86]. There was a small amount of yielding at a column base, but this is expected behavior when the column bases are fixed. Self-centering column bases similar to the self-centering beam-to-column connections have been developed to eliminate this source of damage $[93,48]$. Bottom flange beam yielding was reported during a maximum considered earthquake (MCE) test, but this is the expected response under this very rare earthquake according to the design objectives [41]. There was essentially no residual drift under the MCE.

\subsection{Self-Centering Braces for Steel Braced Frames}

Self-centering braces return to their original length after undergoing axial elongation or shortening. One self-centering brace that has been developed uses a restoring force mechanism consisting of two concentric tubes precompressed by aramid fiber PT strands and an energy dissipation mechanism using friction pads [15]. Figure 9 schematically shows the configuration of telescoping concentric tubes and PT elements for the restoring force mechanism [47]. Several researchers have developed self-centering braces that use shape memory alloy (SMA) wires [20,94,95]. Some use telescoping mechanisms (e.g., $[17,94,95]$ ) similar in concept to the one shown in Figure 9, while others make use of the superelastic SMA material behavior directly to create self-centering [20]. There have been a number of 
generalized research programs into the use of SMA for seismic design of structures starting in the early 1990's [96] and including large research projects in Europe (e.g., MANSIDE project [97]), and in the U.S. (e.g., [98]). SMA materials are "superelastic," which means very large strains (up to 10\%) can be recovered elastically upon the removal of load.

Figure 9. Schematic representation of concentric telescoping tubes used in self-centering braces (adapted from [47]. Copyright John 2014 Wiley \& Sons, Ltd.). (a) Brace subjected to shortening; (b) Brace subjected to elongation.

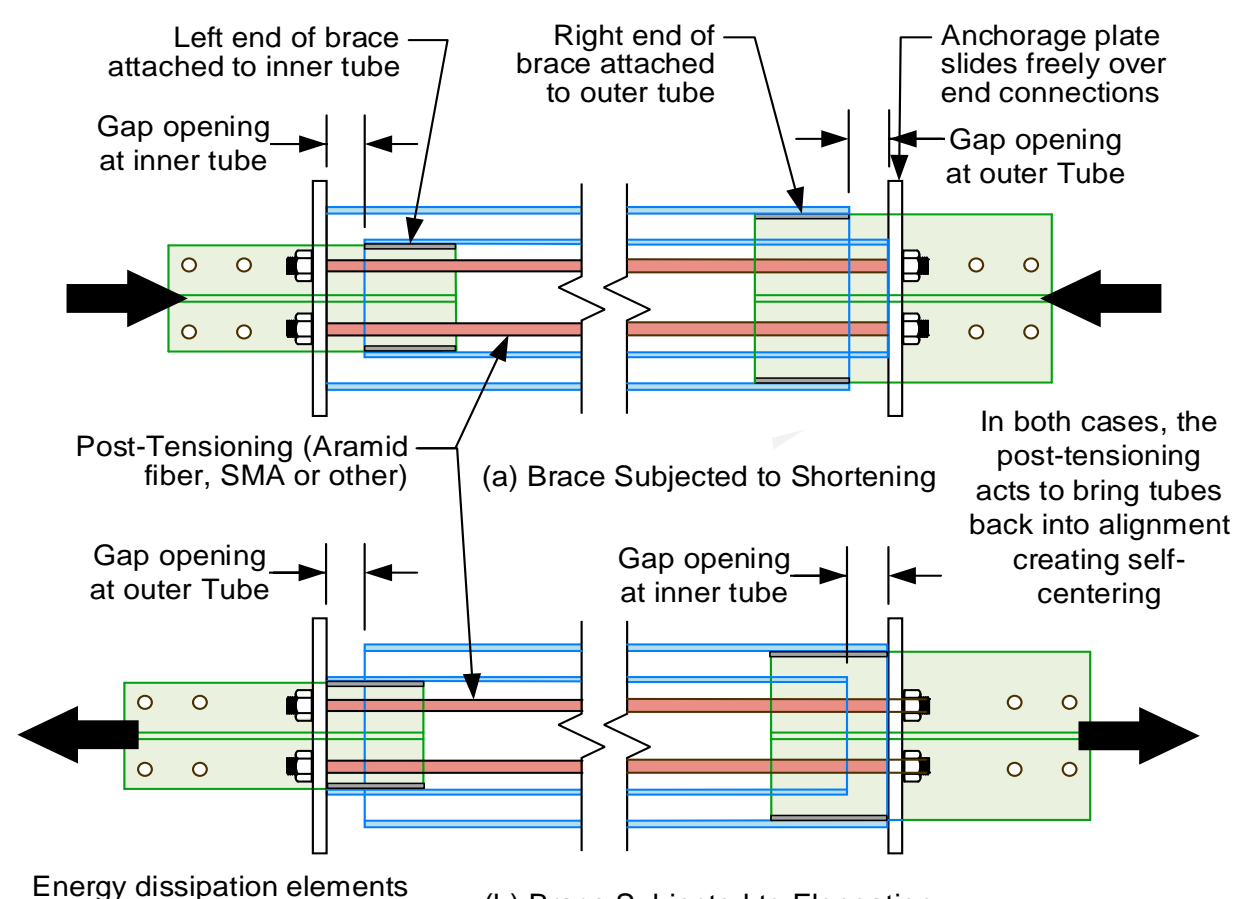

not shown for clarity

(b) Brace Subjected to Elongation

Computational studies of prototype buildings show that self-centering braces that do not have full self-centering hysteretic behavior (i.e., the load-deformation curve does not pass near zero displacement when the lateral load is removed), can still reliably limit residual drifts to negligible magnitude [47]. Computational studies [47] and shake table testing [99] show that prototype buildings constructed with self-centering braces can dissipate significant energy, exhibit peak drifts similar to conventional systems, and nearly eliminate residual drifts.

\subsection{Self-Centering Timber Systems}

To improve seismic performance and reduce structural damage of multi-story timber buildings, self-centering timber systems have been proposed [100-102]. Several configurations of self-centering timber systems have been investigated, including post-tensioned beam-to-column subassemblies, wall, and frame systems [100,101]. In addition to using post-tensioned bars and gap-opening mechanisms to provide self-centering behavior, internal and external energy dissipaters have also been provided [100-102]. Experimental tests on self-centering timber systems have shown these systems to be highly ductile, while still self-centering [100,101]. 
Coupled rocking timber walls with U-shaped energy dissipaters, which were also used in post-tensioned concrete rocking shear walls [64,65], were also examined [101]. Based on experimental results, coupled rocking timber walls with U-shaped energy dissipaters have better seismic performance and increased drift capacity compared to single rocking timber walls [101].

Although past studies on self-centering timber systems have been carried out in New Zealand [100,101], there is an increasing interest and ongoing research projects in other countries (e.g., the United States) as well (e.g., [103]). Promising experimental test results have encouraged the construction of structures with self-centering timber systems in New Zealand [102].

\section{Some Current Research Challenges in Self-Centering Seismic Lateral Force Resisting Systems}

\subsection{Isolating Deformations Related to Gap Opening}

A key component of most self-centering systems is the gap opening mechanism. The gap opening mechanism allows for nonlinear elastic behavior of the structure. However, allowing gaps to form between beam-to-column connections in moment resisting frames and at the base of rocking systems presents connection detailing challenges. These challenges are outlined in this section.

\subsubsection{Floor Diaphragm Connections in Self-Centering Moment Resisting Frames}

In conventional moment resisting frames, the concrete floor diaphragm transfers seismic inertial forces from the floor diaphragm to each beam in the moment resisting frame, as shown schematically in Figure 10a. Transferring load to every beam in the moment resisting frame is problematic for self-centering moment resisting frames. When lateral load is applied to the self-centering moment resisting frame, gaps open at the interface between the end of the beam and the column face. Since there is very little axial shortening of the beam, this gap opening causes the length of the frame to grow [51], as shown in Figure 11; however, the floor diaphragm restrains the expansion of the frame. Limiting frame expansion will affect the behavior of the frame and may damage the floor diaphragm. One proposed detail [51] to address this problem is shown schematically in Figure 10b, in which the floor diaphragm is attached to only one beam in the moment resisting frame per floor. The floor diaphragm and beams in all other bays of the moment resisting frame are non-composite, permitting the beam to move relative to the floor diaphragm. In another study, the frame expansion problem is eliminated by providing the rocking joints at the opposite ends of the beam to have counteracting behavior. A type of post-tensioned rocking connection detail [75] is proposed in which the connection is permitted to rock only about beam bottom flange while the contact of the beam top flange with the column is preserved at all time. Other diaphragm and gravity beam connection details have also been proposed $[85,92,104]$ to address the frame expansion issue. 
Figure 10. Schematic floor diaphragm connection. (a) Floor diaphragm connection to conventional moment resisting frame (MRF); (b) Floor diaphragm connection to self-centering MRF (SC-MRF).

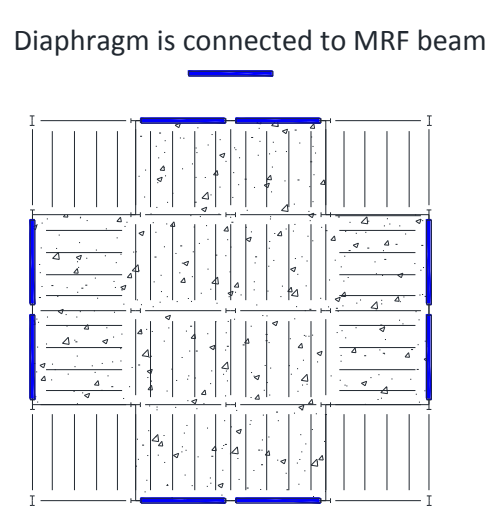

(a)

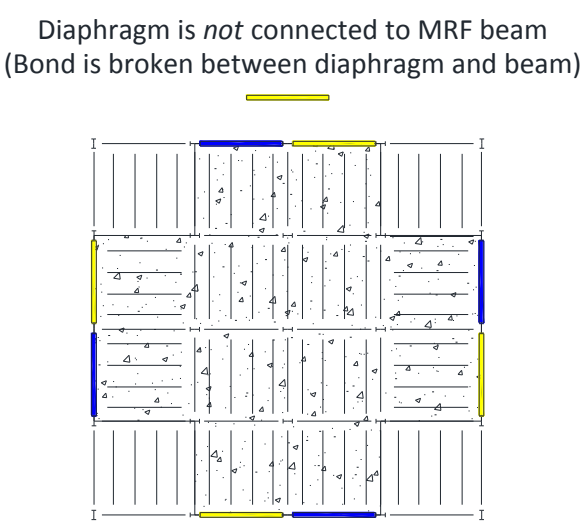

(b)

Figure 11. Frame expansion in self-centering moment resisting frames.
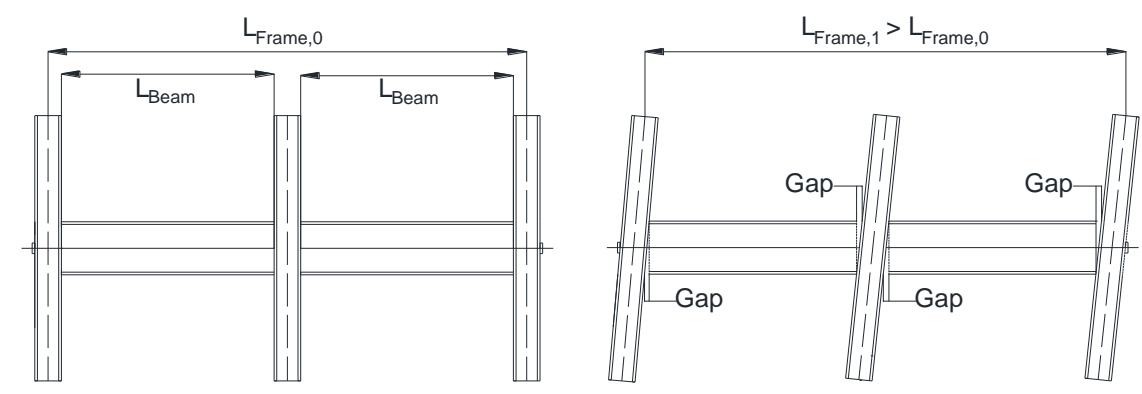

\subsubsection{Floor Diaphragm Connections in Rocking Self-Centering Systems}

Column uplift in rocking self-centering systems can cause local floor damage and may create challenges in connecting the floor system to the rocking frames. There are two general approaches for connecting the diaphragm to a rocking frame or rocking wall: (1) isolating the rocking element from the diaphragm to limit damage; and (2) connecting the diaphragm to the rocking element and accepting local damage.

Figure 12a shows one possible configuration for isolating a rocking steel braced frame from the gravity framing and floor diaphragm. The collector forces are transferred from an adjacent gravity framing column into the rocking frame column through a bearing connection. The bearing can be a low friction connection or a controlled friction interface used to dissipate seismic energy [11]. As an alternative, shear plates capable of transferring shear while allowing uplift could be connected between the rocking frame beams and adjacent gravity framing beams.

Figure $12 \mathrm{~b}$ shows the approach wherein gravity framing and the floor diaphragms are connected directly to the rocking frame beam (e.g., [64]). Localized damage would be expected around the uplifting columns. If gravity framing beams are connected to uplifting columns, the rotational demands can be magnified as compared to those of typical gravity connections, particularly if the adjacent gravity beam span is short. A modified collector detail that can transfer axial force while allowing large rotations may be desirable. 
Shear plates with strategically slotted holes (some vertical, some horizontal) have been used in practice [105]. Additionally, true pins or top flange plates with horizontally slotted web holes are also possible. If rocking frames or walls are placed on the perimeter of a building, it may also be necessary to detail the building façade to accommodate the vertical motion of the rocking system.

Figure 12. Approaches for attaching rocking frames to surrounding gravity framing. (a) Isolating the rocking frame from the gravity framing; (b) Direct attachment of the rocking frame to the gravity framing.

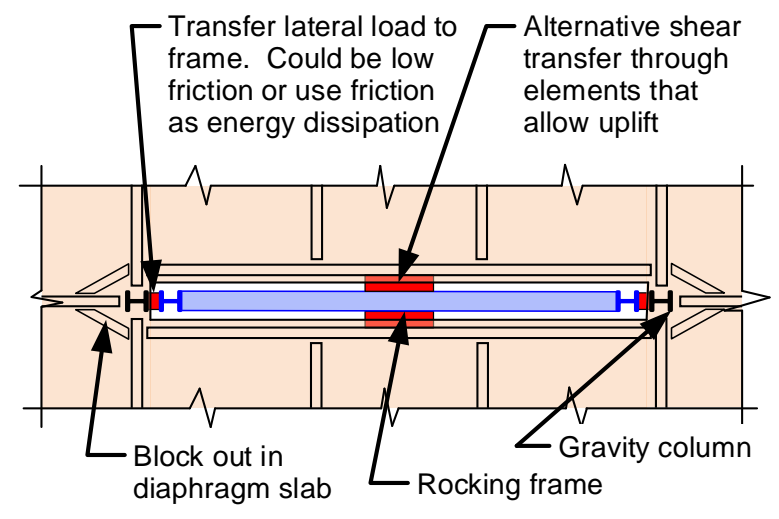

(a)

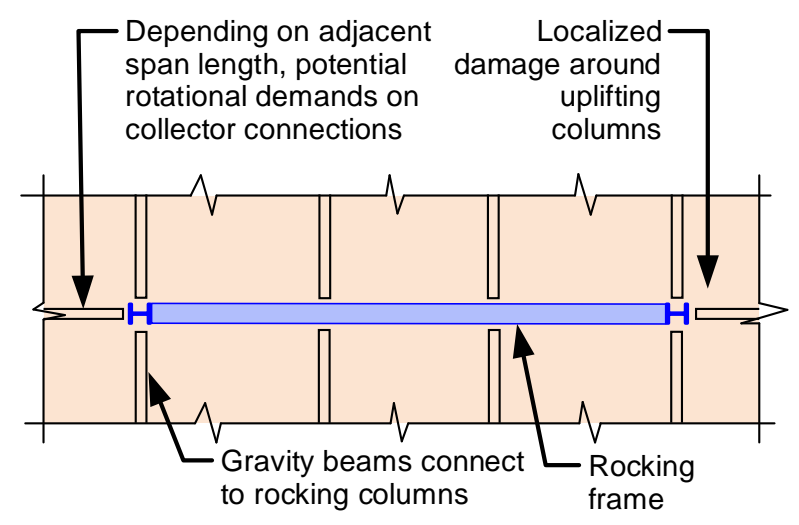

(b)

\subsection{Higher Mode Effects}

Researchers have recognized for some time that building code provisions do not adequately account for higher mode effects [64] and the effects are particularly pronounced for rocking self-centering systems $[10,76]$. As described in a previous section, the inter-story shear forces associated with the first mode are reduced because rocking is allowed, but higher modes can produce inter-story shear forces significantly larger than those predicted by the building code (e.g., [4,11]). Although design approaches have been proposed such as applying modal load factors in response spectrum analysis [4,11], more research is needed to accurately quantify and predict higher mode response in self-centering systems.

An alternative to designing for the unreduced higher mode response in rocking structures involves adding multiple softening mechanisms throughout the building height to limit the higher mode response (e.g., [76]). Placing the uplifting mechanism only at the base of the wall or frame can limit the base overturning moment, but does not limit the base shear, story shears, or story moments. Analytical and experimental studies [77,78] have shown that these other response parameters, which may be controlled by higher modes rather than the first mode, can be reduced by placing additional softening mechanisms into the structure. These additional restoring force mechanisms might be additional rocking mechanisms at other stories in the structure, shear type mechanisms using self-centering braces, or both. While this approach appears promising, further research is needed on this topic.

\subsection{Collapse Safety Assessment of Self-Centering Systems}

Self-centering seismic lateral force resisting systems are used to reduce or eliminate damage under design level earthquakes. However, under very rare and intense earthquakes, even self-centering systems 
may be damaged such that collapse resistance must be assessed. The Federal Emergency Management Agency (FEMA) has adopted a methodology for assessing the safety of seismic lateral force resisting systems and evaluating new systems for inclusion in future building code provisions (FEMA P695) [106]. Under this methodology, archetype structures incorporating the seismic lateral force resisting systems are modeled and subjected to a suite of ground motion records using nonlinear response-history analysis. The ground motion records are applied to the nonlinear numerical model and incrementally increased until at least $50 \%$ of the ground motion records cause the structure to collapse. The probability of collapse is then established for a hazard level with $2 \%$ probability of exceedance in 50 years. Collapse safety assessment of self-centering systems is important if these systems are to be included in building code previsions. Published research on collapse safety assessment of self-centering structures is currently very limited (e.g., $[107,108])$ and is an ongoing topic of research.

\subsection{Efficiency and Strategic Use of Self-Centering Systems Considering Life-Cycle Cost}

The development of self-centering systems is driven by socio-economic costs; high post-earthquake costs show the need for a damage-free alternative to conventional seismic lateral force resisting systems. Self-centering systems were developed to increase the drift capacity prior to structural damage; however, in some cases, there is additional complexity in design, fabrication, and erection of the self-centering system, which may increase construction costs. Though these increased construction costs have not been directly quantified, there is an expectation that the savings due to the damage-free performance of self-centering systems in strong earthquakes will offset the increased initial cost over the life of the structure.

For a building to be damage-free, more than just the seismic lateral force resisting system must remain undamaged. The gravity force resisting system, floor diaphragms, and nonstructural elements must also be serviceable after an earthquake to achieve damage-free building performance [109]. Therefore, life-cycle cost analysis must consider not only the structural repair costs, but all elements of the structure. Quantifying the life-cycle costs of self-centering seismic lateral force resisting systems compared to those of conventional seismic lateral force resisting systems is the subject of ongoing [110-112] and future research.

\section{Conclusions}

Conventional seismic lateral force resisting systems dissipate seismic energy through distributed damage to primary structural elements and residual drifts, which can result in significant socio-economic losses due to repair costs and business downtime. This review outlined the need for new seismic lateral force resisting systems that remain essentially undamaged and virtually eliminate residual drift after design level earthquakes so the building may be occupied immediately after the earthquake. A new class of seismic lateral force resisting systems, self-centering systems, has been developed to meet this need.

Self-centering systems capitalize on a nonlinear elastic gap opening mechanism and concentrate damage in replaceable energy dissipation elements without damaging the structural elements. Post-tensioning across the gap opening joint provides post-gap opening stiffness and self-centering capability as the post-tensioning force acts to close the gap. Energy dissipation devices (e.g., yielding, viscous, and friction) dissipate the seismic energy and are replaceable. The hysteretic behavior for 
self-centering systems is fundamentally different from that for conventional seismic lateral force resisting systems; self-centering systems dissipate less energy per displacement cycle, but exhibit no residual drift. Limit states for self-centering systems are reasonably well defined. The strength of the individual components can be proportioned such that the progression of limit states prevents damage to the seismic lateral force resisting system under design level earthquakes. Ductility demands on self-centering systems can be larger than for conventional systems due to reduced hysteretic damping, but self-centering systems can be designed and detailed to have significantly higher ductility capacity than conventional seismic lateral force resisting systems.

There are multiple types of self-centering seismic lateral force resisting systems, but these systems fall into three broad categories: rocking systems, moment resisting frames, and self-centering braces. Rocking systems have been developed and studied for unbonded post-tensioned concrete shear walls and steel braced frames (with and without post-tensioning). Laboratory tests of concrete and steel rocking self-centering systems have shown that these systems have little or no structural damage under design level earthquakes. Self-centering moment resisting frames made from steel and precast concrete have been studied. Steel self-centering moment resisting frames have been noted to be lighter than conventional steel moment resisting frames while providing damage free performance [86], which potentially makes them cost-competitive with the conventional steel moment resisting frames. Self-centering braces have been developed that can undergo large axial deformations and return to their original length without damage.

Ongoing challenges for self-centering systems include detailing to accommodate gap openings, designing rocking systems for higher mode effects, collapse assessment, and life-cycle cost analysis. Detailing to accommodate gap opening in the structure is an issue for both self-centering moment resisting frames and rocking systems. Details have been proposed and studied to accommodate the gap opening behavior. The response of higher modes is significant for rocking systems and must be appropriately accounted for in member design or mitigated to satisfy damage resistant performance goals. Strategies for both cases were described herein. Collapse safety assessment of self-centering systems is also an important issue for providing adequate structural reliability and is an ongoing topic of research. Because self-centering systems are expected to have a higher initial construction cost than conventional systems, but are expected to pose lower costs over the life of the structure, ongoing research is being conducted to quantify life cycle costs so that architects and engineers can make educated choices about using self-centering seismic systems.

Self-centering seismic lateral force resisting systems have been shown to reduce or eliminate structural damage associated with conventional lateral force resisting systems during significant earthquakes. High-performance self-centering structural systems have the potential to reduce socio-economic loss and disruption of cities after significant earthquakes. Self-centering seismic structural systems are an important tool for building the resilient, sustainable city of tomorrow.

\section{Conflicts of Interest}

The authors declare no conflicts of interest. 


\section{References}

1. Building Seismic Safety Council (BSSC). NEHRP Recommended Provisions for Seismic Regulations for New Buildings and Other Structures: FEMA 450; BSSC: Washington, DC, USA, 2003.

2. Eguchi, R.T.; Goltz, J.D.; Taylor, C.E.; Chang, S.E.; Flores, P.J.; Johnson, L.A.; Blais, N.C. Direct economic losses in the Northridge earthquake: A three-year post-event perspective. Earthq. Spectra 1998, 14, 245-264.

3. Eatherton, M.R.; Toellner, B.W.; Watkins, C.E.; Abbas, E. The Effect of Powder Actuated Fasteners on the Seismic Performance of Protected Zones in Steel Moment Frames. In Proceedings of the Structures Congress, Pittsburgh, PA, USA, 2-4 May 2013.

4. Chancellor, N.B. Seismic Design and Performance of Self-Centering Concentrically-Braced Frames. Ph.D. Thesis, Department of Civil and Environmental Engineering, Lehigh University, Bethlehem, PA, USA, 2014.

5. Field Manual: Postearthquake Safety Evaluation of Buildings; Applied Technology Council (ATC): Redwood City, CA, USA, 2005.

6. New Zealand 2013 Treasury Budget Speech. Available online: http://www.treasury.govt.nz/ budget/2013/speech/06.htm (accessed on 14 May 2014).

7. Canterbury Earthquake Recovery Authority. Available online: http://cera.govt.nz/news/2014/ new-program-to-show-progress-of-public-projects-14-may-2014 (accessed on 14 May 2014).

8. Kiggins, S.; Uang, C.M. Reducing residual drift of buckling-restrained braced frames as a dual system. Eng. Struct. 2006, 28, 1525-1532.

9. Holden, T.; Restrepo, J.; Mander, J.B. Seismic performance of precast reinforced and prestressed concrete walls. J. Struct. Eng. 2003, 129, 286-296.

10. Palermo, A.; Pampanin, S.; Marriott, D. Design, modeling, and experimental response of seismic resistant bridge piers with posttensioned dissipating connections. J. Struct. Eng. 2007, 133, $1648-1661$.

11. Roke, D.; Sause, R.; Ricles, J.M.; Chancellor, N.B. Damage-Free Seismic-Resistant Self-Centering Concentrically-Braced Frames; ATLSS Report 10-09; Lehigh University: Bethlehem, PA, USA, 2010.

12. Rahman, M.A.; Sritharan, S. Performance-based seismic evaluation of two five-story precast concrete hybrid frame buildings. J. Struct. Eng. 2007, 133, 1489-1500.

13. Ricles, J.M.; Sause, R.; Garlock, M.M.; Zhao, C. Posttensioned seismic-resistant connections for steel frames. J. Struct. Eng. 2001, 127, 113-121.

14. Kurama, Y.C.; Weldon, B.D.; Shen, Q. Experimental evaluation of posttensioned hybrid coupled wall subassemblages. J. Struct. Eng. 2006, 132, 1017-1029.

15. Christopoulos, C.; Tremblay, R.; Kim, H.J.; Lacerte, M. Self-centering energy dissipative bracing system for the seismic resistance of structures: Development and validation. J. Struct. Eng. 2008, 134, 96-107.

16. Eatherton, M.; Ma, X.; Krawinkler, H.; Deierlein, G.G.; Hajjar, J.F. Quasi-static cyclic behavior of controlled rocking steel frames. J. Struct. Eng. 2014, 2014, doi:10.1061/(ASCE)ST.1943-541X.0001005. 
17. Miller, D.J.; Fahnestock, L.A.; Eatherton, M.R. Development and experimental validation of a nickel-titanium shape memory alloy self-centering buckling-restrained brace. Eng. Struct. 2012, 40, 288-298.

18. Gonner, N.; Chancellor, N.B.; Sause, R.; Ricles, J.M.; Roke, D. Design, Experimental Setup, and Testing of Self-Centering Steel Concentrically-Braced Frame Test Structure; ATLSS Report 10-06; Lehigh University: Bethlehem, PA, USA, 2010.

19. Bruce, T. Behavior of Post-Tensioning Strand Systems Subjected to Inelastic Cyclic Loading. Master Thesis, Virginia Tech, Blacksburg, VA, USA, 2014.

20. Zhu, S.; Zhang, Y. Seismic analysis of concentrically braced frame systems with self-centering friction damping braces. J. Struct. Eng. 2008, 134, 121-131.

21. Chou, C.C.; Chen, Y.C. Development and Seismic Performance of Steel Dual-Core Self-Centering Braces. In Proceedings of the 15th World Conference on Earthquake Engineering, Lisbon, Portugal, 24-28 September 2012.

22. Erochko, J.; Christopoulos, C.; Tremblay, R. Design and Testing of an Enhanced-Elongation Telescoping Self-Centering Energy-Dissipative (T-SCED) Brace. In Proceedings of the 15th World Conference on Earthquake Engineering, Lisbon, Portugal, 24-28 September 2012.

23. Innovation Task Group, American Concrete Institute (ACI). Requirements for Design of Special Unbonded Post-Tensioned Precast Shear Wall Satisfying ACI ITG-5.1 (ACI ITG-5.2-09) and Commentary; ACI ITG-5.2-09, Reported by ACI Innovation Task Group 5; ACI: Farmington Hills, MI, USA, 2009.

24. Midorikawa, M.; Azuhata, T.; Ishihara, T.; Wada, A. Shaking table tests on seismic response of steel braced frames with column uplift. Earthq. Eng. Struct. Dyn. 2006, 35, 1767-1785.

25. Wolski, M.; Ricles, J.M.; Sause, R. Seismic Resistant Self-Centering Steel Moment Resisting Frames with Bottom Flange Friction Devices. In Behavior of Steel Structures in Seismic Areas: 5th International Conference on Behavior of Steel Structures in Seismic Areas; Taylor \& Francis: London, UK, 2006.

26. Garlock, M.M.; Ricles, J.M.; Sause, R. Experimental studies of full-scale posttensioned steel connections. J. Struct. Eng. 2005, 131, 438-448.

27. Christopoulos, C.; Filiatrault, A.; Uang, C.M.; Folz, B. Posttensioned energy dissipating connections for moment-resisting steel frames. J. Struct. Eng. 2002, 128, 1111-1120.

28. Christopoulos, C.; Filiatrault, A.; Folz, B. Seismic response of self-centring hysteretic SDOF systems. Earthq. Eng. Struct. Dyn. 2002, 31, 1131-1150.

29. Seo, C.Y.; Sause, R. Ductility demands on self-centering systems under earthquake loading. ACI Struct. J. 2005, 102, 275.

30. Eatherton, M.R.; Hajjar, J.F. Residual drifts of self-centering systems including effects of ambient building resistance. Earthq. Spectra 2011, 27, 719-744.

31. Pollino, M.; Bruneau, M. Seismic testing of a bridge steel truss pier designed for controlled rocking. J. Struct. Eng. 2010, 136, 1523-1532.

32. Ma, X.; Krawinkler, H.; Deierlein, G. Seismic Design, Simulation and Shake Table Testing of Self-Centering Braced Frame with Controlled Rocking and Energy Dissipating Fuses; Stanford University: Stanford, CA, USA, 2011. 
33. Maurya, A.; Eatherton, M.R. Self-Centering Beams with Resilient Seismic Performance. In Proceedings of the ASCE Structures Congress, Boston, MA, USA, 3-5 April 2014.

34. Takamatsu, T.; Tamai, H.; Yamanishi, T.; Matsuo, A. Self-Centering Performance of Non-Slip-Type Exposed Column-Base. In Behavior of Steel Structures in Seismic Areas: 5th International Conference on Behavior of Steel Structures in Seismic Areas; Taylor \& Francis: London, UK, 2006.

35. Ma, X.; Borchers, E.; Peña, A.; Krawinkler, H.; Deierlein, G. Design and Behavior of Steel Shear Plates with Openings as Energy-Dissipating Fuses; Stanford University: Stanford, CA, USA, 2010.

36. Wada, A.; Yamada, S.; Fukuta, O.; Tanigawa, M. Passive Controlled Slender Structures Having Special Devises at Column Connections. In Proceedings of the 7th International Seminar on Seismic Isolation, Passive Energy Dissipation and Active Control of Vibrations of Structures, Assisi, Italy, 2-5 October 2001.

37. Shen, Q.; Kurama, Y.C. Nonlinear behavior of posttensioned hybrid coupled wall subassemblages. J. Struct. Eng. 2002, 128, 1290-1300.

38. Vasdravellis, G.; Karavasilis, T.L.; Uy, B. Large-scale experimental validation of steel posttensioned connections with web hourglass pins. J. Struct. Eng. 2012, 139, 1033-1042.

39. Toranzo, L.A.; Restrepo, J.I.; Mander, J.B.; Carr, A.J. Shake-table tests of confined-masonry rocking walls with supplementary hysteretic damping. J. Earthq. Eng. 2009, 13, 882-898.

40. Gledhill, S.M.; Sidwell, G.K.; Bell, D.K. The Damage Avoidance Design of tall steel frame buildings-Fairlie Terrace Student Accomodation Project, Victoria University of Wellington. In Proceedings of the 2008 New Zealand Society for Earthquake Engineering, Wellington, New Zealand, 11-13 April 2008.

41. Lin, Y.C.; Sause, R.; Ricles, J. Seismic performance of a large-scale steel self-centering moment-resisting frame: MCE hybrid simulations and quasi-static pushover tests. J. Struct. Eng. 2012, 139, 1227-1236.

42. Tremblay, R.; Poirier, L.P.; Bouaanani, N.; Leclerc, M.; Rene, V.; Fronteddu, L.; Rivest, S. Innovative Viscously Damped Rocking Braced Steel Frames. In Proceedings of the 14th World Conference on Earthquake Engineering, Beijing, China, 12-17 October 2008.

43. Kam, W.Y.; Pampanin, S.; Palermo, A.; Carr, A.J. Self-centering structural systems with combination of hysteretic and viscous energy dissipations. Earthq. Eng. Struct. Dyn. 2010, 39, 1083-1108.

44. El-Sheikh, M.T.; Sause, R.; Pessiki, S.; Lu, L.W. Seismic behavior and design of unbonded post-tensioned precast concrete frames. PCI J. 1999, 44, 54-71.

45. Kurama, Y.C. Simplified seismic design approach for friction-damped unbonded post-tensioned precast concrete walls. ACI Struct. J. 2001, 98, 705-716.

46. MacRae, G.A.; Kawashima, K. Post-earthquake residual displacements of bilinear oscillators. Earthqu. Eng. Struct. Dyn. 1997, 26, 701-716.

47. Eatherton, M.R.; Fahnestock, L.A.; Miller, D. Computational study on the behavior of self-centering buckling restrained braces. Earthq. Eng. Struct. Dyn. 2014, doi:10.1002/eqe.2428.

48. Chi, H.; Liu, J. Seismic behavior of post-tensioned column base for steel self-centering moment resisting frame. J. Constr. Steel Res. 2012, 78, 117-130. 
49. Gad, E.F.; Chandler, A.M.; Duffield, C.F.; Stark, G. Lateral behavior of plasterboard-clad residential steel frames. J. Struct. Eng. 1999, 125, 32-39.

50. Roke, D.; Sause, R.; Ricles, J.M.; Seo, C.Y.; Lee, K.S. Self-Centering Seismic-Resistant Steel Concentrically-Braced Frames. In Proceedings of the 8th US National Conference on Earthquake Engineering, San Francisco, CA, USA, 18-22 April 2006.

51. Garlock, M.M.; Sause, R.; Ricles, J.M. Behavior and design of posttensioned steel frame systems. J. Struct. Eng. 2007, 133, 389-399.

52. Kurama, Y.; Pessiki, S.; Sause, R.; Lu, L.W. Seismic behavior and design of unbonded post-tensioned precast concrete walls. PCI J. 1999, 44, 72-89.

53. Perez, F.J.; Pessiki, S.; Sause, R. Seismic design of unbonded post-tensioned precast concrete walls with vertical joint connectors. PCI J. 2004, 49, 58-79.

54. Perez, F.J.; Sause, R.; Pessiki, S. Analytical and experimental lateral load behavior of unbonded posttensioned precast concrete walls. J. Struct. Eng. 2007, 133, 1531-1540.

55. Perez, F.J.; Pessiki, S.; Sause, R.; Lu, L.W. Lateral load tests of unbonded post-tensioned precast concrete walls. ACI Spec. Publ. 2003, 211, 161-182.

56. Lin, Y.C.; Ricles, J.M.; Sause, R.; Seo, C.Y. Earthquake Simulations on a Self-Centering Steel Moment Resisting Frame with Web Friction Devices. In Proceedings of the 14th World Conference on Earthquake Engineering, Beijing, China, 12-17 October 2008.

57. Seo, C.Y. Influence of Ground Motion Characteristics and Structural Parameters on Seismic Responses of SDOF Systems. Ph.D. Thesis, Department of Civil and Environmental Engineering, Lehigh University, Bethlehem, PA, USA, 2005.

58. Tremblay, R.; Lacerte, M.; Christopoulos, C. Seismic response of multi-storey buildings with self-centering energy dissipative steel braces. J. Struct. Eng. 2008, 134, 108-120.

59. Priestley, M.J.N.; Tao, J.R. Seismic response of precast prestressed concrete frames with partially debonded tendons. PCI J. 1993, 38, 58-69.

60. Eatherton, M.; Ma, X.; Krawinkler, H.; Billington, S.; Hajjar, J.F.; Deierlein, G. Design concepts for controlled rocking of self-centering steel-braced frames. J. Struct. Eng. 2014, 2014, doi:10.1061/(ASCE)ST.1943-541X.0001047.

61. Buchanan, A.H.; Bull, D.; Dhakal, R.; MacRae, G.; Palermo, A.; Pampanin, S. Base Isolation and Damage-Resistant Technologies for Improved Seismic Performance of Buildings; Technical Report 2011-02 for the Royal Commission of Inquiry into Building Failure Caused by the Canterbury Earthquakes; University of Canterbury: Christchurch, New Zealand, 2011.

62. Kurama, Y.C. Hybrid post-tensioned precast concrete walls for use in seismic regions. PCIJ. 2002, 47, 36-59.

63. Smith, B.; Kurama, Y.; McGinnis, M. Comparison of Hybrid and Emulative Precast Concrete Shear Walls for Seismic Regions. In Proceedings of the ASCE Structures Congress, Las Vegas, NV, USA, 14-16 April 2011.

64. Priestley, N.M.J.; Sritharan, S.; Conley, J.R.; Pampanin, S. Preliminary results and conclusions from the PRESSS five-story precast concrete test building. PCI J. 1999, 44, 42-67.

65. Aaleti, S.; Sritharan, S. A simplified analysis method for characterizing unbonded post-tensioned precast wall systems. Eng. Struct. 2009, 31, 2966-2975. 
66. Restrepo, J.I.; Rahman, A. Seismic performance of self-centering structural walls incorporating energy dissipators. J. Struct. Eng. 2007, 133, 1560-1570.

67. Marriott, D.; Pampanin, S.; Palermo, A. Quasi-static and pseudo-dynamic testing of unbonded post-tensioned rocking bridge piers with external replaceable dissipaters. Earthq. Eng. Struct. Dyn. 2009, 38, 331-354.

68. Kurama, Y.C.; Shen, Q. Posttensioned hybrid coupled walls under lateral loads. J. Struct. Eng. 2004, 130, 297-309.

69. Clough, R.W.; Huckelbridge, A.A. Preliminary Experimental Study of Seismic Uplift of a Steel Frame; Earthquake Engineering Research Center (EERC) Report No. UCB/EERC-77-22; University of California: Berkeley, CA, USA, 1977.

70. Kelley, J.; Tsztoo, D. Earthquake Simulation Testing of a Stepping Frame with Energy-Absorbing Devices; Earthquake Engineering Research Center (EERC) Report No. EERC 77-17; University of California: Berkeley, CA, USA, 1977.

71. Eatherton, M.; Hajjar, J.; Ma, X.; Krawinkler, H.; Deierlein, G. Seismic Design and Behavior of Steel Frames with Controlled Rocking-Part I: Concepts and Quasi-Static Subassembly Testing. In Proceedings of the ASCE Structures Congress, Orlando, FL, USA, 12-15 May 2010.

72. Ma, X.; Eatherton, M.; Hajjar, J.; Krawinkler, H.; Deierlein, G. Seismic Design and Behavior of Steel Frames with Controlled Rocking-Part II: Large Scale Shake Table Testing and System Collapse Analysis. In Proceedings of the ASCE Structures Congress, Orlando, FL, USA, 12-15 May 2010.

73. Pollino, M. Structural and Non-Structural Seismic Demands on Controlled Rocking Steel Braced Frame Buildings. In Proceedings of the ASCE Structures Congress, Chicago, IL, USA, 29-31 March 2012.

74. Roke, D.; Sause, R.; Ricles, J.M.; Gonner, N. Design Concepts for Damage-Free Seismic Resistant Self-Centering Steel Concentrically-Braced Frames. In Proceedings of the 14th World Conference on Earthquake Engineering, Beijing, China, 12-17 October 2008.

75. Dowden, D.M.; Bruneau, M. NewZ-BREAKSS: Post-tensioned rocking connection detail free of beam growth. AISC Eng. J. 2011, 48, 153-158.

76. Wiebe, L.; Christopoulos, C. Mitigation of higher mode effects in base-rocking systems by using multiple rocking sections. J. Earthq. Eng. 2009, 13, 83-108.

77. Wiebe, L.; Christopoulos, C.; Tremblay, R.; Leclerc, M. Mechanisms to limit higher mode effects in a controlled rocking steel frame. 1: Concept, modeling, and low-amplitude shake table testing. Earthq. Eng. Struct. Dyn. 2013, 42, 1053-1068.

78. Wiebe, L.; Christopoulos, C.; Tremblay, R.; Leclerc, M. Mechanisms to limit higher mode effects in a controlled rocking steel frame. 2: Large-amplitude shake table testing. Earthq. Eng. Struct. Dyn. 2013, 42, 1069-1086.

79. Morgen, B.G.; Kurama, Y.C. Seismic response evaluation of posttensioned precast concrete frames with friction dampers. J. Struct. Eng. 2008, 134, 132-145.

80. Priestley, M.N. Overview of PRESSS research program. PCI J. 1991, 36, 50-57.

81. Priestley, M.N. The PRESSS program: Current status and proposed plans for phase III. PCI J. 1996, 41, 22-40. 
82. Englekirk, R.E. Design-construction of the paramount-A 39-story precast prestressed concrete apartment building. PCI J. 2002, 47, 56-71.

83. Ricles, J.M.; Sause, R.; Peng, S.W.; Lu, L.W. Experimental evaluation of earthquake resistant posttensioned steel connections. J. Struct. Eng. 2002, 128, 850-859.

84. Wolski, M.; Ricles, J.M.; Sause, R. Experimental study of a self-centering beam-Column connection with bottom flange friction device. J. Struct. Eng. 2009, 135, 479-488.

85. Kim, H.J.; Christopoulos, C. Friction damped posttensioned self-centering steel moment-resisting frames. J. Struct. Eng. 2008, 134, 1768-1779.

86. Lin, Y.C.; Sause, R.; Ricles, J.M. Seismic performance of steel self-centering, moment-resisting frame: Hybrid simulations under design basis earthquake. J. Struct. Eng. 2013, 139, 1823-1832.

87. Clayton, P.M.; Berman, J.W.; Lowes, L.N. Seismic design and performance of self-centering steel plate shear walls. J. Struct. Eng. 2011, 138, 22-30.

88. Dowden, D.M.; Purba, R.; Bruneau, M. Behavior of self-centering steel plate shear walls and design considerations. J. Struct. Eng. 2011, 138, 11-21.

89. Clayton, P.M.; Berman, J.W.; Lowes, L.N. Subassembly testing and modeling of self-centering steel plate shear walls. Eng. Struct. 2013, 56, 1848-1857.

90. Tsai, K.C.; Chou, C.C.; Lin, C.L.; Chen, P.C.; Jhang, S.J. Seismic self-centering steel beam-to-column moment connections using bolted friction devices. Earthq. Eng. Struct. Dyn. 2008, 37, 627-645.

91. Kim, H.J.; Christopoulos, C. Numerical models and ductile ultimate deformation response of post-tensioned self-centering moment connections. Earthq. Eng. Struct. Dyn. 2009, 38, 1-21.

92. Chou, C.C.; Chen, J.H. Seismic design and shake table tests of a steel post-tensioned self-centering moment frame with a slab accommodating frame expansion. Earthq. Eng. Struct. Dyn. 2011, 40, 1241-1261.

93. Chi, H.; Liu, J.; Garlock, M. Design and Analytical Validation of Post-Tensioned Column Bases. In Proceedings of the ASCE Structures Congress, Vancouver, Canada, 24-26 April 2008.

94. Dolce, M.; Cardone, D. Theoretical and experimental studies for the application of shape memory alloys in civil engineering. J. Eng. Mater. Technol. 2006, 128, 302-311.

95. Yang, W.C.S.; DesRoches, R.; Leon, R.T. Design and analysis of braced frames with shape memory alloy and energy-absorbing hybrid devices. Eng. Struct. 2010, 32, 498-507.

96. Graesser, E.J.; Cozzarelli, F.A. Shape-memory alloys as new materials for aseismic isolation. J. Eng. Mech. 1991, 117, 2590-2608.

97. Dolce, M.; Cardone, D. Mechanical behavior of shape memory alloys for seismic applications. 1. Martensite and austenite NiTi bars subjected to torsion. Int. J. Mech. Sci. 2001, 43, 2631-2656.

98. DesRoches, R.; McCormick, J.; Delemont, M. Cyclic properties of superelastic shape memory alloy wires and bars. J. Struct. Eng. 2004, 130, 38-46.

99. Erochko, J.; Christopoulos, C.; Tremblay, R.; Kim, H.J. Shake table testing and numerical simulation of a self-centering energy dissipative braced frame. Earthq. Eng. Struct. Dyn. 2013, 42, $1617-1635$. 
100. Pampanin, S.; Palermo, A.; Buchanan, A.H.; Fragiacomo, M.; Deam, B.L. Code Provisions for Seismic Design of Multi-Storey Post-Tensioned Timber Buildings. In Proceedings of the 39th Meeting of the Working Commission W18-Timber Structures, CIB, International Council for Research and Innovation, Florence, Italy, 28-31 August 2006.

101. Buchanan, A.; Deam, B.; Fragiacomo, M.; Pampanin, S.; Palermo, A. Multi-storey prestressed timber buildings in New Zealand. Struct. Eng. Int. 2008, 18, 166-173.

102. Palermo, A.; Sarti, F.; Baird, A.; Bonardi, D.; Dekker, D.; Chung, S. From Theory to Practice: Design, Analysis and Construction of Dissipative Timber Rocking Post-Tensioning Wall System for Carterton Events Center, New Zealand. In Proceedings of the 15th World Conference on Earthquake Engineering, Lisbon, Portugal, 24-28 September 2012.

103. Pei, S.; Berman, J.; Dolan, D.; van de Lind, J.; Ricles, J.; Sause, R.; Blomgren, H.E.; Popovski, M.; Rammer, D. Progress on the Development of Seismic Resilient Tall CLT Buildings in the Pacific Northwest. In Proceedings of the 2014 World Conference on Timber Engineering, Quebec City, Canada, 10-14 August 2014.

104. Chou, C.C.; Chen, J.H. Development of floor slab for steel post-tensioned self-centering moment frames. J. Constr. Steel Res. 2011, 67, 1621-1635.

105. Mar, D. Design Examples Using Mode Shaping Spines For Frame and Wall Buildings. In Proceedings of the 9th US National and 10th Canadian Conference on Earthquake Engineering, Toronto, Canada, 25-29 July 2010.

106. Quantification of Building Seismic Performance Factors: FEMA P695; Federal Emergency Management Agency: Washington, DC, USA, 2009.

107. Tahmasebi, E.; Chancellor, N.B.; Sause, R.; Ricles, J.M.; Joó, A.L.; Akbas, G. Collapse Performance of Steel Self-Centering Braced Frame Systems. In Proceedings of the 7th International Conference on Behavior of Steel Structures in Seismic Areas, Santiago, Chile, 9-11 January 2012.

108. Tahmasebi, E.; Sause, R.; Ricles, J.M.; Chancellor, N.B.; Akbas, T. Probabilistic Collapse Performance Assessment of Self-Centering Concentrically Braced Frames. In Proceedings of the 10th U.S. National Conference on Earthquake Engineering, Anchorage, AK, USA, 21-25 July 2014.

109. MacRae, G. Low Damage construction-Some Systems Issues. In Proceedings of the 10th International Conference on Urban Earthquake Engineering, Tokyo, Japan, 1-2 March 2013.

110. Roke, D.A.; Chandra, A.; Huang, Q.; Sett, K. Methodology for Life Cycle Cost Assessment of Self-Centering Concentrically Braced Frame Systems. In Proceedings of the 10th International Conference on Urban Earthquake Engineering, Tokyo, Japan, 1-2 March 2013.

111. Dyanati, M.; Huang, Q.; Roke, D.A. Seismic Performance and Economic Feasibility Evaluation of Self-Centering Concentrically-Braced-Frame System. In Proceedings of the 11th International Conference on Structural Safety and Reliability, New York, NY, USA, 16-20 June 2013.

112. Dyanati, M.; Huang, Q.; Roke, D.A. Structural and Nonstructural Performance Evaluation of Self-Centering, Concentrically Braced Frames Under Seismic Loading. In Proceedings of the ASCE Structures Congress, Boston, MA, USA, 3-5 April 2014.

(C) 2014 by the authors; licensee MDPI, Basel, Switzerland. This article is an open access article distributed under the terms and conditions of the Creative Commons Attribution license (http://creativecommons.org/licenses/by/3.0/). 